\title{
TEBAL LEMAK PUNGGUNG DAN LUAS DAGING MATA RUSUK BABI GROWER YANG DIBERI GULA AREN (Arenga pinnata Merr) DALAM AIR MINUM
}

\author{
Marisa V Ango, Mien Th.R. Lapian*, Jeanette M.E. Soputan, Surtijono E. \\ Siswosubroto
}

\author{
Fakultas Peternakan Universitas Sam Ratulangi, Manado 95115
}

\begin{abstract}
ABSTRAK
Penelitian ini bertujuan untuk mengetahui pengaruh penggunaan gula aren dalam air minum babi fase grower terhadap tebal lemak punggung, dan luas daging mata rusuk. Penelitian ini menggunakan 16 ekor babi. Variabel penelitian adalah konsumsi air minum, tebal lemak punggung, dan luas daging mata rusuk. Metode penelitian adalah Rancangan Acak Kelompok yang terdiri dari 4 kelompok berat badan dan 4 perlakuan level gula aren dalam air minum yaitu $0,2,4$ dan $6 \%$, kemudian dilanjutkan dengan menggunakan uji BNT. Hasil analisis sidik ragam menunjukan bahwa perlakuan berpengaruh sangat nyata terhadap konsumsi air minum $(\mathrm{P}<0,01)$. Hasil uji lanjut $\mathrm{BNT}$ untuk jumlah konsumsi air minum menunjukan bahwa R0 (0\%) berbeda nyata dengan R1 (2\%), R2 (4\%), R3 (6\%) dan R1 (2\%) tidak berbeda nyata dengan penggunaan gula aren R2 (4\%) dan R3 (6\%). Demikian juga perlakuan berpengaruh pada luas daging mata rusuk $(\mathrm{P}<0,05)$, tapi tidak berpengaruh pada tebal lemak punggung $(\mathrm{P}>0,05)$ tetapi termasuk ke dalam kelas karkas No.1 $(<3,56$ $\mathrm{cm})$. Hasil uji BNT menunjukkan bahwa R0 $(0 \%)$ berbeda nyata dengan R1 $(2 \%), \mathrm{R} 2(4 \%)$ dan R3 $(6 \%)$ terhadap luas daging mata rusuk sedangkan R1 (2\%) tidak berbeda nyata dengan R2 (4\%) dan R3 (6\%). Berdasarkan hasil penelitian menunjukkan bahwa penggunaan gula aren sampai $2 \%$ dapat meningkatkan jumlah konsumsi air minum yaitu 7,78 liter/hari dan luas daging mata rusuk yaitu $43,72 \mathrm{~cm}^{2}$ tetapi tidak untuk lemak punggung.

Kata Kunci : Babi, Gula Aren, Tebal lemak punggung, Urat Daging Mata Rusuk
\end{abstract}

*Korespondensi (corresponding author)

Email : lapian_linda@yahoo.com

\section{ABSTRACT}

\section{BACKFAT THICKNESS AND LOIN EYE AREA GROWER PIG USING PALM SUGAR (Arenga pinnata Merr) INTO DRINKING WATER. The research was} conducted to determine the effect of the use of palm sugar in drinking water of pigs grower to the backfat thickness, and loin eye area. This study using 16 pigs. The research variables are drinking water consumption, backfat thickness and loin eye area.The research method is a randomized block design consisting of 4 weight group and 4 treatment of palm sugar levels in drinking water are $0,2,4$ and $6 \%$, followed by the use of LSD. Analysis of variance showed that the treatment is very significant effect on water consumption ( $\mathrm{P}$ $<0.01)$. Further test results BNT to the amount of consumption of drinking water shows that the R0 (0\%) significantly different from R1 (2\%), R2 (4\%), R3 (6\%) and R1(2\%) was not significantly different from the use of palm sugar R2 (4\%) and R3(8,91 L). Likewise, the treatment effect on loin eye area $(\mathrm{P}<0.05)$ with an average of $43.72 \mathrm{~cm} 2$, but had no effect on backfat thickness ( $\mathrm{P}>0.05)$ with the average of $2.79 \mathrm{~cm}$ even which in the first class category of carcass $(<3.56 \mathrm{~cm})$. The LSD shows that R0 $\left(36,44 \mathrm{~cm}^{2}\right)$ significantly different from the R1(47,17 $\left.\mathrm{cm}^{2}\right), \mathrm{R} 2(44,33$ $\left.\mathrm{cm}^{2}\right)$ and R3 $\left(46,99 \mathrm{~cm}^{2}\right)$ to the loin eye area while not significantly different from R1 $\left(47,14 \mathrm{~cm}^{2}\right)$ to R2 $\left(44,33 \mathrm{~cm}^{2}\right)$ and R3 $(46,99$ $\mathrm{cm}^{2}$ ). Based on the results of the study indicate that the use of palm sugar to $2 \%$ can increase the amount of water consumption is 7.78 liters/day and loin eye area is $43.72 \mathrm{~cm}^{2}$ but not for backfat thickness.

Keywords : Pig, palm sugar, backfat thickness, loin eye area 


\section{PENDAHULUAN}

Ternak babi merupakan salah satu komoditas ternak penghasil daging yang memiliki potensi besar untuk dikembangkan karena memiliki sifat sifat dan kemampuan yang menguntungkan antara lain laju pertumbuhan yang cepat, jumlah anak perkelahiran yang tinggi, efisiensi ransum yang baik dan presentase karkas yang tinggi (Siagian, 2005). Ternak babi selain sebagai penghasil protein hewani juga mendatangkan keuntungan bagi peternak. Menurut BPS Sulawesi Utara (2014), populasi ternak babi sekitar 404.968 ekor, populasi ini jauh lebih tinggi jika dibandingkan dengan ternak besar lainnya, karena masyarakat gemar mengkonsumsi daging babi.

Karkas merupakan bagian tubuh ternak hasil pemotongan dikurangi dengan darah, kepala, kaki, kulit, organ dalam seperti jantung, hati, paru - paru, limpa, saluran pencernaan dan saluran reproduksi (Soeparno, 2005). Karkas terdiri dari daging tulang dan lemak. Menurut Krider dan Carol (1971), tebal lemak punggung merupakan salah satu parameter dalam menentukan kualitas karkas, karena 2/3 bagian dari total lemak karkas adalah lemak subkutan. Tebal lemak punggung dan luas urat daging mata rusuk berkaitan erat dengan pengklasifikasian kualitas karkas. Luas urat daging mata rusuk diukur diantara tulang ke 10 dan 11 (Miller et al. 1991).

Agar memperoleh produksi karkas yang optimal ternak babi membutuhkan nutrisi yang sesuai dengan kebutuhannya dalam hal ini untuk memperbaiki kualitas karkas. Walaupun pada kenyataannya zat zat nutrisi yang diberikan sudah terpenuhi namun belum tentu ternak dapat memanfaatkannya dengan baik sehingga menyebabkan kerugian bagi peternak. Oleh karena itu digunakan gula aren yang dicampur dalam air minum ternak babi. Gula aren memiliki nutrisi mineral, dan energi yang tinggi serta mengandung glukosa, protein kasar, dan vitaminvitamin. Salah satu vitamin dalam gula aren yang memiliki peran penting yaitu vitamin $B_{2}$ (riboflavin), di mana vitamin ini dapat membantu melancarkan proses metabolisme dalam sistem pencernaan dan mengoptimalkan sel-sel tubuh. Disamping itu glukosa, memiliki peran penting yaitu penyerapannya berlangsung lambat di dalam tubuh. Karena lambatnya penyerapan maka pasokan energi juga berlangsung lambat sehingga mengakibatkan tubuh bugar lebih lama (Sapari, 1995). Di Sulawesi utara potensi gula aren cukup besar dan telah menjadi produk ekspor. Gula aren mudah larut, 
keadaannya kering, bersih serta aromanya khas dan memilki warna khas yaitu warna cokelat yang mengandung serat yang dapat diserap oleh sistem pencernaan dengan baik.

Berdasarkan pembahasan diatas, maka telah dilakukan penelitian tentang pengaruh perlakuan terhadap konsumsi air, tebal lemak punggung dan luas urat daging mata rusuk".

\section{MATERI DAN METODE PENELITIAN}

\section{Lokasi dan Waktu Penelitian}

Penelitian ini telah dilaksanakan di kota Tomohon Kelurahan Woloan 1 pada Peternakan babi milik Bapak Rudy Wondal melalui suatu pra percobaan selama 2 minggu sedangkan pengumpulan data berlangsung selama 71 hari.

\section{Materi Penelitian}

Penelitian ini menggunakan ternak babi fase grower sebanyak 16 ekor dengan kisaran bobot badan 43,3 - 58,5 kg. Kandang yang digunakan adalah kandang individu yang berukuran panjang 150 x 90 x $100 \mathrm{~cm}$, dan dilengkapi dengan tempat makan dan minum (niple), serta dibersihkan 2 kali sehari. Ransum penelitian yang digunakan dalam percobaan ini terdiri dari konsentrat $30 \%$, jagung $70 \%$. Penggunaan gula aren sebagai bahan perlakuan dicampur dalam air minum prosesnya dapat dilihat pada diagram alir pembuatan larutan gula aren (Gambar 1).

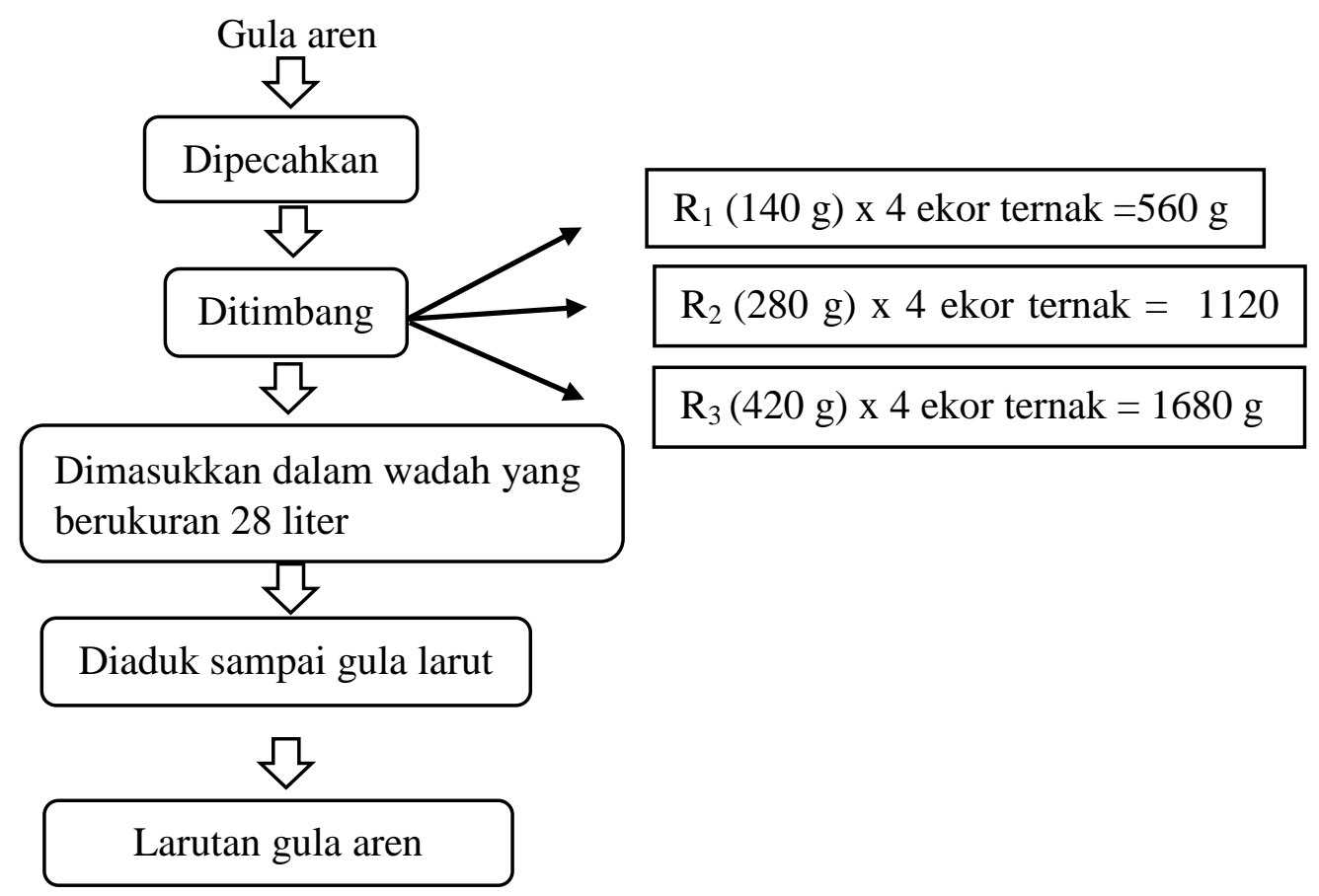

Gambar 1. Diagram alir pembuatan larutan gula aren 
Komposisi ransum yang digunakan dalam penelitian dapat dilihat pada Tabel 1 sedangkan susunan ransum serta komposisi zat - zat makanan dapat dilihat pada Tabel 2 dan jumlah komposisi zat zat makanan lihat Tabel 3 serta hasil analisa komposisi air biasa dan gula aren pada Tabel 4.

\section{Metode Penelitian}

Rancangan penelitian yang digunakan pada percobaan ini adalah rancangan acak kelompok (Steel dan Torrie, 1989) kemudian dilanjutkan dengan uji beda nyata terkecil. Penelitian ini terdiri dari 4 perlakuan dan 4 kelompok berdasarkan bobot badan yaitu :

$\mathrm{R} 0=$ Air minum larutan gula aren $0 \%$

$\mathrm{R} 1=$ Air minum larutan gula aren $2 \%$

R2 = Air minum larutan gula aren $4 \%$

R3 = Air minum larutan gula aren $6 \%$ Sedangkan kelompok berdasarkan bobot badan berkisar antara :

Kelompok :

B1 = Bobot badan 43,5-46,5 $\mathrm{kg}$

B2 = Bobot badan $47,5-50,5 \mathrm{~kg}$

B3 = Bobot badan $51-56,5 \mathrm{~kg}$

B4= Bobot badan $58,5 \mathrm{~kg}$

Semua data diolah dengan menggunakan analisis sidik ragam (Steel dan Torrie, 1989), dengan mengikuti prosedur model linear umum seperti berikut:

$\mathrm{Y}_{i j}=\mu+\tau_{i}+\beta_{\mathrm{j}}+\epsilon_{i j}\left\{\begin{array}{l}i=1,2, \ldots, p \\ j=1,2, \ldots, b\end{array}\right.$

\section{Prosedur Penelitian}

Babi fase grower dengan bobot badan 46,5 - 58,5 kg ditempatkan secara acak pada masing - masing kandang secara individual. Setiap kelompok diberikan perlakuan gula aren dengan konsentrasi $0,2,4$ dan $6 \%$ dalam air minum. Pemberian makan dan minum diberikan ad libitum selama 71 hari, kemudian sisa makanan dan air minum yang diberikan diukur pada pagi hari berikutnya. Setelah dilakukan percobaan selama 71 hari ternak babi kemudian dipotong. Sebelum dipotong babi di puasakan selama 24 jam lalu ditimbang (Lawrie, 2003). Pemotongan dilakukan dengan menusuk bagian leher tepat didepan ujung tulang dada, dengan tujuan memotong vena jugularisnya untuk mengeluarkan darah. Sesudah pengeluaran darah selesai bulu dibersihkan dengan cara dibakar, lalu dilakukan pengeluaran organorgan bagian dalam dan ke empat kuku kaki dikeluarkan kemudian karkas dibelah dua dan dilakukan pengukuran terhadap tebal lemak dan luas urat daging mata rusuk. 
Tabel 1. Komposisi Ransum Percobaan

Bahan makanan (\%)

\begin{tabular}{ll}
\hline Jagung & 70 \\
\hline Konsentrat & 30 \\
\hline
\end{tabular}

Tabel 2. Susunan Ransum Serta Komposisi Zat - Zat Makanan (\%)

\begin{tabular}{|c|c|c|c|c|c|c|c|c|}
\hline $\begin{array}{l}\text { Bahan } \\
\text { makanan }\end{array}$ & $\begin{array}{c}\text { Kadar } \\
\text { air } \\
(\%)\end{array}$ & $\begin{array}{c}\text { Protein } \\
(\%)\end{array}$ & $\begin{array}{c}\text { Lemak } \\
(\%)\end{array}$ & $\begin{array}{l}\text { Sk } \\
(\%)\end{array}$ & $\begin{array}{l}\text { abu } \\
(\%)\end{array}$ & $\begin{array}{l}\mathrm{Ca} \\
(\%)\end{array}$ & $\begin{array}{c}\mathrm{P} \\
(\%)\end{array}$ & $\begin{array}{l}\text { ME } \\
(\text { Kkal)/ } \\
\text { kg }\end{array}$ \\
\hline Konsentrat* & 10 & 39 & 3 & 6 & 34 & - & 0.60 & 3200 \\
\hline Jagung** & - & 9.42 & 5.17 & 2.15 & - & 0.22 & - & 3182 \\
\hline
\end{tabular}

Ket :*) Hasil Analisa PT. CARGILL INDONESIA

**) Hasil Analisa Universitas Padjajaran (2014)

Tabel 3. Jumlah Komposisi Zat - Zat Makanan

\begin{tabular}{lr}
\hline Zat Makanan & $(\%)$ \\
\hline Kadar air & 3.00 \\
Protein & 18.29 \\
Lemak & 4.51 \\
Serat kasar & 3.30 \\
Abu & 10.20 \\
Calsium & 0.15 \\
Phospor & 0.42 \\
Energi metabolis & 3187.40
\end{tabular}

Sumber : Hasil Perhitungan 
Tabel 4. Komposisi Air Biasa dan Gula Aren

\begin{tabular}{|c|c|c|}
\hline Sifat Kimia & Air Biasa*) & Gula Aren**) \\
\hline \multicolumn{3}{|c|}{$(\%)$} \\
\hline Kadar air & 98.81 & 9.45 \\
\hline Bahan kering & - & 90.55 \\
\hline $\mathrm{Abu}$ & - & 1.79 \\
\hline Lemak & - & 0.79 \\
\hline Protein kasar & - & 3.31 \\
\hline Beta- N & - & 84.83 \\
\hline Serat kasar & - & 0.01 \\
\hline Kalium (K) & 1.01 & - \\
\hline Calsium (Ca) & 2.68 & 0.36 \\
\hline Magnesium & 0.64 & - \\
\hline Natrium $(\mathrm{Na})$ & 0.04 & - \\
\hline Besi $(\mathrm{Fe})$ & - & - \\
\hline Phosphor (P) & - & 0.19 \\
\hline Gross Energi (Kkal/kg) & - & 3719 \\
\hline
\end{tabular}

Ket: *) Hasil Analisa Laboratorium Unsrat Manado 1994

**) Hasil Analisa Laboratorium Institut Pertanian Bogor (IPB) 2015

\section{Variabel Penelitian}

Konsumsi air minum dihitung dari jumlah air yang diberikan dikurangi dengan jumlah air sisa pagi hari berikutnya (Lapian, 1995).

Tebal lemak punggung diukur di tiga tempat yaitu di atas tulang rusuk pertama, diatas tulang rusuk terakhir dan diatas tulang belakang terakhir (Thrasher et al., 1970). Alat yang dipakai adalah mistar aluminium.

Pengukuran luas urat daging mata rusuk dilakukan dengan cara melukiskan luas penampang otot longissimus dorsi di antara tulang rusuk ke 10 dan 11, kemudian dihitung dengan menggunakan milimeter blok (Purnamartha et al., 2014).

\section{HASIL DAN PEMBAHASAN}

\section{Konsumsi Air Minum}

Rataan hasil penelitian terhadap konsumsi air minum dapat dilihat pada tabel 5. Rataan hasil penelitian masing masing perlakuan dengan taraf $0,2,4,6$ $\%$ gula aren dalam air minum berada pada kisaran 6,57 - 8,91 liter/ekor/hari, dengan rataan umum 7,96 liter/ekor/hari seperti tercantum pada Tabel 5. Konsumsi air minum pada penelitian ini lebih tinggi dari yang direkomendasikan oleh Anggorodi (1994), bahwa konsumsi air minum ternak babi grower sampai finisher berkisar antara $5.0 \quad-\quad 7.0 \quad$ liter/ekor/hari. 
Tabel 5. Pengaruh Perlakuan Terhadap Konsumsi Air Minum (Liter)

\begin{tabular}{lccccc}
\hline \multirow{2}{*}{ Variabel } & \multicolumn{7}{c}{ Perlakuan } \\
\cline { 2 - 6 } & $\mathrm{R} 0$ & $\mathrm{R} 1$ & $\mathrm{R} 2$ & $\mathrm{R} 3$ & Rataan \\
\hline Konsumsi air minum (L) & $6.57^{\mathrm{a}}$ & $7.78^{\mathrm{b}}$ & $8.57^{\mathrm{bc}}$ & $8.91^{\mathrm{c}}$ & 7,96 \\
Tebal lemak punggung (cm) & 2.72 & 2.78 & 2.80 & 2.88 & 2.79 \\
Luas urat daging mata rusuk $\left(\mathrm{cm}^{2}\right)$ & $36.44^{\mathrm{a}}$ & $47.14^{\mathrm{c}}$ & $44.33^{\mathrm{b}}$ & $46.99^{\mathrm{b}}$ & 43.72 \\
\hline Keterangan: Superskrip huruf yang berbeda pada baris menunjukkan hasil berbeda nyata $(\mathrm{P}<0.05)$
\end{tabular}

Hasil analisis sidik ragam menunjukkan bahwa penggunaan gula aren terhadap konsumsi air minum berbeda sangat nyata $(\mathrm{P}<0,01)$, karena dipengaruhi oleh adanya kandungan glukosa yang membuat air minum terasa manis sehingga membuat ternak banyak minum, hal ini disebabkan oleh semakin tingginya konsentrasi gula aren yang diberikan maka tingkat palatabilitas konsumsi air minum semakin meningkat. Hasil penelitian ini sejalan dengan pendapat Tilman et al, (1998) yang menjelaskan bahwa faktor yang mempengaruhi konsumsi adalah palatabilitas yang meliputi bau, rasa dan tekstur. Hasil analisis sidik ragam untuk Rataan hasil penelitian terhadap tebal lemak punggung dapat dilihat pada tabel 5. Rataan hasil penelitian masing masing perlakuan dengan taraf $0,2,4,6$ $\%$ gula aren dalam air minum berada pada kisaran $2.77-2.88 \mathrm{~cm}$, dengan rataan umum 2,79 $\mathrm{cm}$ seperti tercamtum pada Tabel 5. Hasil penelitian ini termasuk dalam kelas No 1 seperti yang direkomendasikan oleh USDA (1985), kelompok yang berdasarkan bobot badan tidak berbeda nyata $(P>0,05)$, hal ini dapat dijelaskan bahwa bobot badan tidak mempengaruhi konsumsi air minum.

Hasil uji lanjut BNT (lampiran 3) menunjukan bahwa penggunaan gula aren $(0 \%)$ berbeda nyata dengan penggunaan gula aren 2, 4 dan 6\%. Penggunaan gula aren $2 \%$, tidak berbeda nyata dengan penggunaan gula aren 4 dan $6 \%$. Hal ini disimpulkan bahwa penggunaan gula aren mulai $2 \%$ sudah meningkatkan konsumsi air minum. Hal ini berarti semakin tinggi konsentrasi yang diberikan maka semakin tinggi jumlah konsumsi air minum.

\section{Tebal Lemak Punggung}

untuk kelas karkas US No.1 (<3.56 cm), No.2 (3.57 - $4.32 \mathrm{~cm})$, No.3 (4.33 - 5.08 $\mathrm{cm})$ dan kelas No.4 (5.08 cm). Hasil penelitian sejalan dengan Siagian et al. (2005) yang meneliti pengaruh substitusi jagung dengan corn gluten feed dalam ransum terhadap kualitas karkas babi dan analisis ekonomi memperoleh nilai rataan tebal lemak punggung 2,53 cm. Hasil analisis sidik ragam menunjukkan bahwa 
pengaruh perlakuan penggunaan gula aren tidak berbeda nyata $(\mathrm{P}>0,05)$, demikian pula dengan kelompok yang berdasarkan bobot badan tidak menunjukkan perbedaan yang nyata $(\mathrm{P}>0,05)$ terhadap tebal lemak punggung. Hal ini berarti penggunaan gula aren menunjukkan hasil yang sama terhadap tebal lemak punggung. Walaupun secara statistik tidak berbeda nyata tetapi ada kecenderungan dengan penggunaan gula aren dalam air minum dapat menurunkan tebal lemak punggung. Rendahnya tebal lemak punggung pada penelitian ini karena gula aren mengandung serat yang dapat diserap oleh sistem pencernaan dengan baik, juga sangat penting untuk proses pencernaan didalam tubuh. (Lutony, 1993).

\section{Luas Urat Daging Mata Rusuk}

Rataan hasil penelitian terhadap luas urat daging mata rusuk dapat dilihat pada tabel 5. Rataan hasil penelitian penggunaan gula aren dalam air minum dengan taraf $0,2,4$, dan $6 \%$ berkisar antara $36,44-46,99 \mathrm{~cm}^{2}$ dengan rataan umum adalah $43,72 \mathrm{~cm}^{2}$. Hasil penelitian ini lebih tinggi dari yang diteliti Soulsby (1982), bahwa nilai rata - rata luas urat daging mata rusuk pada periode finisher yaitu $42,97 \mathrm{~cm}^{2}$. Hasil penelitian sejalan dengan hasil Lapian et al. (2013), yang meneliti kualitas karkas babi potong yang dilahirkan dari induk yang disuperovulasi sebelum pengawinan memperoleh nilai rataan luas urat daging mata rusuk sebesar $42,39 \mathrm{~cm}^{2}$.

Hasil analisis sidik ragam (lampiran 7) menunjukkan bahwa penggunaan gula aren dalam air minum ternak babi memberikan pengaruh yang berbeda nyata $(\mathrm{P}<0,05)$ terhadap luas urat daging mata rusuk, karena gula aren mengandung protein yang dapat digunakan oleh ternak sebagai sumber asam amino untuk membentuk daging (Silalahi dan Sinaga, 2010). Selain itu gula aren memiliki kandungan nutrisi seperti vitamin $B_{2}$ (riboflavin), thiamin, niacin, ascorbic acid, dan salah satu kandungan nutrisi yang berperan penting yaitu riboflavin yang merupakan prekursor dari koenzim penting tertentu seperti flavin mononukleotida (FMN) dan flavin - flavin dinukleotida (FAD), yang berpartisipasi dalam oksidasi dan reaksi reduksi dari beberapa proses metabolisme, seperti oksidasi pengangkutan elektron mitokondria, asam lemak dengan asam amino dan siklus asam sitrat (Rivlin, 2006). Riboflavin berkontribusi terhadap energi makanan, membantu mengubah makanan menjadi energi, dibutuhkan untuk pelepasan energi dari protein, lemak dan karbohidrat, dan membantu dalam metabolisme karbohidrat, protein dan lemak (Efsa, 
2013). Hasil analisis sidik ragam untuk kelompok yang berdasarkan bobot badan tidak berbeda nyata $(\mathrm{P}>0,05)$, hal ini dapat dijelaskan bahwa bobot badan tidak mempengaruhi luas urat daging mata rusuk.

$$
\text { Hasil uji BNT (lampiran 8) }
$$
menunjukkan penggunaan gula aren $0 \%$ berbeda nyata penggunaan gula aren 2,4 dan $6 \%$ terhadap luas urat daging mata rusuk. sedangkan penggunaan gula aren $2 \%$ tidak berbeda nyata dengan pengunaan gula aren 4 dan 6\%. Hal ini dapat disimpulkan bahwa penggunaan gula aren sampai $2 \%$ sudah dapat meningkatkan luas urat daging mata rusuk.

\section{KESIMPULAN}

Berdasarkan hasil penelitian menunjukkan bahwa penggunaan gula aren sampai $2 \%$ dapat meningkatkan jumlah konsumsi air minum yaitu 7,78 liter/hari dan luas urat daging mata rusuk yaitu $43,72 \mathrm{~cm}^{2}$ tetapi tidak untuk lemak punggung.

\section{DAFTAR PUSTAKA}

Badan Pusat Statistik Propinsi Sulawesi Utara. 2014. Populasi Ternak Menurut Kabupaten/Kota dan Jenis Ternak di Sulawesi Utara. Diambil tanggal 23 Februari 2016.
http://sulut.bps.go.id/linkTabelStatis/ view/id/69

Efsa. 2013. Scientific Opinion on the substantiation of a health claim related to riboflavin (vitamin B2) and contribution to normal energyyielding metabolism pursuant to Article 14 of Regulation (EC) No 1924/20061. EFSA Journal. 11(10):3410.

Krider, J.L. and W.E. Carrol. 1971. Swine Production. 4th ed. Mc Graw-Hill International Book Co. New Delhi.

Lapian, M.Th.R. 1995. Penggunaan Ampas Dan Air Kelapa Terhadap Penampilan Dan Nilai Karkas Ternak Babi Pengakhiran. Tesis. Fakultas Peternakan Institut Pertanian Bogor, Bogor.

Lapian, M.Th.R., P.H. Siagian, W. Manalu, and R. Priyanto. 2013. Carcass qualities of finisher pig born to superovulated sows before mating. Jurnal Veteriner. Vol 14(3): 350-357

Lawrie, R. A. 2003. Meat Science. Second edition. Oxford. Pergamon Press.

Lutony, T.L. 1993. Tanaman Sumber Pemanis. P.T Penebar Swadaya, Jakarta.

Miller, E. R., D. E. Ullery and J.F. Lewis. 1991. Swine Nutririon. Butterworth Heineman. Stoneham, USA.

Purnamartha, I.M., Setiyono and Panjono. 2014. The effect of rice hull in the dried hotel food waste based-diet on the growth and carcass of pigs. Buletin Peternakan. Vol. 38(1): 51 58 
Rivlin, R.S. 2006. Riboflavin. In: Present Knowledge in Nutrition. Eds Bowman BA and Russell RM, ILSI Press, Washington DC, USA, 250258.

Sapari, Ahmad. 1995. Teknik Membuat Gula Aren. Karya Anda, Surabaya.

Siagian, P.H., S. Natasasmita, dan P. Silalahi. 2005. Pengaruh substitusi jagung dengan corn gluten feed (cgf) dalam ransum terhadap kualitas karkas babi dan analisis ekonomi. Media Peternakan. Vol.28(3): 100108

Sihombing, D.T.H. 1983. Ilmu Produksi Ternak Babi. Fakultas Peternakan, Institut Pertanian Bogor, Bogor.

Silalahi, M. dan S. Sinaga. 2010. Pengaruh pemberian tepung kulit buah pepaya (carica papaya) dalam ransum babi periode finisher terhadap persentase karkas tebal lemak punggung dan luas urat daging mata rusuk. Prosiding Seminar Nasional Teknologi Peternakan Dan Veteriner. Fakultas Peternakan Universitas Padjajaran, Bandung. Hal: $680-685$.
Soeparno. 2005. Ilmu dan Teknologi Daging. Gadjah Mada University Press, Yogyakarta.

Soulsby, E.J.L. 1982. Helminths, Antropods and Protozoa of Domesticated Animals. Inglish Laguage Book Service Bailiere Tindall. 7th Ed. pp. $231-257$.

Steel, R.D.G. and J. H. Torrie. 1989. Prinsip dan Prosedur Statistik. Suatu Tinjauan Biometrik. Edisi Bahasa Indonesia. P. T. Gramedia, Jakarta.

Thrasher, G.W., J.E. Shively, C.E. Askelon, W.E. Babcock, R.R. Chaquest. 1970. Effects of carbadox on performance and carcass traits of growing swine. J.Animal Science $1: 333-338$

Tillman AD, Hartadi H, Reksohadiprodjo S, Prawirokusumo S, Lebdosoekojo S. 1998. Ilmu Makanan Ternak Dasar. Cetakan Kedua. Gadjah Mada University- Press, Yogyakarta.

USDA. United State of Departement Agriculture. 1997. United States Standars for Grades of Carcass Beef. National Agricultural Statistics Service, Mt An 1-2-1 (00). 